ORIGINAL ARTICLE / ARTIGO ORIGINAL

\title{
Factors associated with depression: sex differences between residents of Quilombo communities
}

\author{
Fatores associados à depressão: diferenças por sexo em moradores de \\ comunidades quilombolas
}

Sabrina Martins Barroso', Ana Paula Melo", Mark Drew Crosland Guimarães"II

\begin{abstract}
Introduction: The Quilombola population is subject to numerous sources of social vulnerability, but few studies investigate their physical or mental health conditions. Objectives: To investigate the factors associated with depression in men and women, separately. Methodology: Cross-sectional population-based study with 764 randomly selected participants from five quilombo communities in Vitória da Conquista, Bahia, Brazil. The cutoff point for depression was $\geq 10$ points, assessed by the Patient Health Questionnaire score (PHQ-9), and the presence of five or more symptoms. We estimated the prevalence ratio with $95 \%$ confidence intervals using Poisson regression models with robust estimators stratified by gender. Results: Among men, factors associated with depression were previous diagnosis of chronic illnesses, poor/very poor health selfassessment, and poor access to health services. Among women, the associated factors were previous diagnosis of psychiatric disorders, poor/very poor health self-perception, history of tobacco smoking, and self-declaration of race as not black. Conclusion: Factors associated with depression differ between men and women and must be considered in interventions to fight depression within this population.
\end{abstract}

Keywords: Depression. Sex factors. Association. Rural health. Diagnosis. Public health.

'Universidade Federal de Minas Gerais; Department of Psychology, Universidade Federal do Triângulo Mineiro - Uberaba (MG), Brazil. "Department of Medicine, Universidade Federal de São João Del Rei - Divinópolis (MG), Brazil.

"'Department of Preventive and Social Medicine, Medical School, Universidade Federal de Minas Gerais - Belo Horizonte (MG), Brazil. Corresponding author: Sabrina Martins Barroso. Psychology Degree, Educational Center of the Universidade Federal do Triângulo Mineiro. Avenida Getulio Guaritá, 159, sala 320. CEP: 38025-440, Uberaba, MG, Brazil. E-mail: sa.barroso@yahoo.com.br Conflict of interests: nothing to declare - Financial support: This study is part of a doctoral thesis that received financial support from the Bahia Research Foundation (FAPESB) and the Minas Gerais Research Foundation (FAPEMIG). 
RESUMO: Introdução: A população quilombola está sujeita a inúmeros fatores de vulnerabilidade social, mas poucos estudos investigam suas condições de saúde física ou mental. Objetivos: Investigar os fatores associados à depressão para homens e mulheres. Metodologia: Estudo populacional, transversal, com 764 participantes selecionados aleatoriamente em 5 comunidades quilombolas de Vitória da Conquista, Bahia, Brasil. A depressão foi definida por $\geq 10$ pontos avaliados pela escala Patient Health Questionnaire (PHQ-9) e presença de 5 ou mais sintomas. Estimou-se a razão de prevalência, com intervalo confiança de $95 \%$ por meio de regressão de Poisson com estimadores robustos, estratificada por sexo. Resultados: Para os homens, os fatores associados à depressão foram diagnóstico prévio de doença crônica, autoavaliação de saúde ruim/muito ruim e acesso ruim aos serviços de saúde. Para as mulheres, os fatores associados foram diagnóstico prévio de transtorno psiquiátrico, autoavaliação de saúde ruim/muito ruim, histórico de tabagismo e se autodeclarar como não negra. Conclusão: Os fatores associados à depressão diferem entre homens e mulheres e precisam ser considerados nas intervenções para combater a depressão nessa população.

Palavras-chave: Depressão. Fatores sexuais. Associação. Saúde da população rural. Diagnóstico. Saúde pública.

\section{INTRODUCTION}

The worldwide prevalence of depression is estimated between 2.2 and $10.4 \%{ }^{1}$. In Brazil, the National Household Sample Survey (PNAD) conducted in 2008 assessed the prevalence of depression in the general population at $4.1 \%{ }^{2}$. Studies conducted in different countries indicate the severity of the disease ${ }^{3}$, its epidemic nature ${ }^{4}$, its high cost for healthcare services ${ }^{5}$, and its relationship with factors of social vulnerability ${ }^{1}$. Another common finding is the observation of higher prevalence of depression among women, at a ratio of $2: 1^{3}$.

Explanations for the higher prevalence of female depression include hypotheses of biological reaction to stress ${ }^{6}$, double workdays ${ }^{7}$, and use of less effective coping strategies ${ }^{8}$. Differences between men and women are not restricted to the prevalence of depression. Some studies found differences in terms of responses to treatment with antidepressants ${ }^{9}$, in the ability to remember mood swings ${ }^{10}$, and in the modulation of depressive symptoms ${ }^{11}$. However, other studies indicate the absence of gender differences in the prevalence of depression in cultures in which there is greater female appreciation ${ }^{12}$, and in specific subpopulations, as is the case with African Americans ${ }^{13}$, young Israelis ${ }^{14}$, and Orthodox Jews residing in London ${ }^{10}$.

Investigations into the mental health of traditional Brazilian populations are very scarce, but one study ${ }^{15}$ indicated a $29 \%$ prevalence of depression among Karajás Indians. The Quilombolas are another traditional Brazilian subpopulation. The Quilombolas are an Afro-Brazilian social group descending from slaves, who live in rural areas where there were quilombo settlements during the slavery period, and that still connects with the black culture $^{16,17}$. In 1988, the Brazilian government acknowledged the Quilombola rights and granted them land ownership. However, the Quilombola territories are predominantly rural areas, with little infrastructure and limited access to healthcare services, which portrays their vulnerability and raises questions about their physical and mental health ${ }^{16,17}$. Despite their 
history of ethnic and social victimization, the Quilombolas have been neglected in public health policies ${ }^{16,18}$ and few studies have investigated their health conditions ${ }^{18-21}$.

With regard to mental health, a study ${ }^{20}$ investigated the Quilombola community from Caiana dos Crioulos, Paraíba, and found the presence of alcoholism and mental problems. Another one $^{21}$, focusing on depression in the Quilombola community in Bahia, observed the prevalence of a disorder similar to the one present in the general Brazilian population and the absence of gender differences in prevalence and intensity of depressive symptoms. Studies on this subject are still scarce ${ }^{18,21}$, and, to date, none had investigated gender differences in the determinants of mental illness within this population. Considering the lack of information about the Quilombola population and the factors associated with depression for each gender, this study aimed to analyze the factors associated with depression in adult men and women residing in Quilombola communities in the Vitória da Conquista County, Bahia, stratified by gender.

\section{METHODS}

\section{STUDY AND PARTICIPANT DESIGN}

This is a cross-sectional population-based study, designed to assess several health determinants in Quilombola communities in the Vitória da Conquista County, Bahia (COMQUISTA Project), in 2011. The County had 25 Quilombola communities certified by the Palmares Cultural Foundation in the period of the study, divided into five districts. For the definition of the sample, one community per district, communities with over 50 households, household data collection, randomized household selection, in proportion to community size, inclusion of all residents older than 18 years old from the selected households, census estimation of 2-3 residents per household, prevalence of $50 \%$, investigation of multiple events, accuracy level of $5 \%, 95 \%$ confidence level, design effect $=2$, and estimated loss of $30 \%$ were considered. By these criteria, there were 2,935 eligible adults and the sample was set at 884 individuals. At the end of data collection, losses were $12 \%$, making the total of 764 respondents and presenting a satisfactory sample power for the identification of prevalence of depression and the factors associated with this condition in this population, from the prevalence ratio of 1.1. The methodological details of the COMQUISTA Project may be obtained from a methodological paper on the subject ${ }^{22}$.

\section{INSTRUMENT AND PROCEDURE}

The studied outcome was depression, classified as positive screening for a major depressive episode, by the Patient Health Questionnaire (PHQ-9). The presence of depression was considered when the individual scored 10 or more points in the PHQ-9 and revealed the presence of five or more symptoms in the scale, among which depressed mood and/ or anhedonia on most days are required. The PHQ-9 comprises nine statements related to the 15 previous days, based on nine criteria for diagnosing depression from the Diagnostic and Statistical Manual of Mental Disorders, 
$4^{\text {th }}$ edition. For each statement, four possible responses are provided, ranging from 0 (never) and 3 (almost every day), with the highest possible score of 27 points ${ }^{23}$. The adequacy of the scale to be used in the Quilombola community was previously investigated using the Item Response Theory (IRT). This analysis identifies the capability of each item of an instrument to obtain information about the investigated event, to discriminate between groups according to the responses given, and also the possible difficulties in understanding items ${ }^{24}$.

Data were collected by trained interviewers in individual interviews, using an adaptation of the National Health Survey questionnaire, the adequacy of which was tested in a pilot study ${ }^{22}$. The following variables were considered: gender, age, education, unemployment, placement in the job market before the age of 16 , having suffered physical or sexual violence, participation in group and religious activities, regular physical activity, TV watching, alcohol consumption, history of tobacco smoking, previous self-reported medical diagnosis of chronic illnesses and/ or psychiatric disorders, health self-assessment, use of health services in the past year, and rating of overall access to health services. The access rate was established by examining healthcare services (composition of healthcare professional teams) and household (registration with a Basic Health Unit and number of visits by the community health workers) characteristics ${ }^{21}$.

The study was approved by the Research Ethics Committee from Universidade Federal de Minas Gerais and Universidade São Francisco de Barreiras, and all participants signed the informed consent form.

\section{STATISTICAL ANALYSIS}

In the first instance, descriptive analyses stratified by gender were performed and the gender differences among the Quilombolas were assessed using measures of central tendency and the $\chi^{2}$ test. Potential factors associated with depression were investigated by bivariate and multivariate analyses, stratified by gender. Poisson regression models with robust estimators stratified by gender were used to obtain the prevalence ratio (PR) with $95 \%$ confidence interval $(95 \% \mathrm{CI})$. Following indications from the literature ${ }^{25}$, for the multivariate analyses, all variables with $p$-Value $\leq 0.20$ in the bivariate analyses were considered, while only the significant variables $(\mathrm{p} \leq 0.05)$ remained in the final models for each gender. The adequacy of the final models was verified by means of the Goodness-of-fit and Omnibus tests. Statistical analyses were performed using the SAS software, Version 9.0.

\section{RESULTS}

\section{DESCRIPTIVE ANALYSIS}

From the 884 subjects determined for the sample, 764 were interviewed, 355 (46.4\%) of which were men and 409 (53.6\%) were women. Participants who were not found after three 
visits, who refused to participate in the study, or who did not fully fill out the instruments were excluded, totaling 50 men and 37 women.

Depression was observed in $10.4 \%$ men and in $13.4 \%$ women, and no statistical differences between genders were indicated. Women described themselves mostly as black, were younger, had higher unemployment rates, began to work later, got more diagnoses of chronic illnesses, used healthcare services more frequently, and participated more in religious activities than men (Table 1). Men participated more in group activities and volunteer work, reported more physical activity, and presented more alcohol and cigarette consumption than women.

Table 1. Characteristics of participants by gender, separately. Vitória da Conquista, BA, Brazil, $2011(n=764)$.

\begin{tabular}{|c|c|c|c|c|c|c|}
\hline \multirow[t]{2}{*}{ Individual Variables } & \multicolumn{2}{|c|}{$\begin{array}{c}\text { Men } \\
(n=355)\end{array}$} & \multicolumn{2}{|c|}{$\begin{array}{l}\text { Women } \\
(n=409)\end{array}$} & \multirow{2}{*}{$\begin{array}{c}\chi^{2} \text { by } \\
\text { gender }\end{array}$} & \multirow[t]{2}{*}{ p-value } \\
\hline & $n$ & $\%$ & $\mathrm{n}$ & $\%$ & & \\
\hline Depression & 37 & 10.4 & 55 & 13.4 & 1.62 & 0.202 \\
\hline \multicolumn{7}{|c|}{ Socioeconomic characteristics } \\
\hline \multicolumn{7}{|l|}{ Color/race } \\
\hline Black & 286 & 80.6 & 356 & 87.0 & & \\
\hline Not black & 69 & 19.4 & 53 & 13.0 & 5.9 & 0.015 \\
\hline \multicolumn{7}{|l|}{ Quilombola } \\
\hline No & 63 & 17.7 & 52 & 12.7 & 3.8 & 0.052 \\
\hline Yes & 292 & 82.3 & 357 & 87.3 & & \\
\hline \multicolumn{7}{|l|}{ Marital status } \\
\hline In a relationship & 222 & 62.5 & 252 & 61.6 & 0.1 & 0.793 \\
\hline Not in a relationship & 133 & 37.5 & 157 & 38.4 & & \\
\hline \multicolumn{7}{|l|}{ Age (in years) } \\
\hline $18-40$ & 154 & 43.4 & 217 & 53.1 & 7.1 & 0.008 \\
\hline $41+$ & 201 & 56.6 & 192 & 46.9 & & \\
\hline \multicolumn{7}{|c|}{ Education (in years of school completed) } \\
\hline $5+$ & 104 & 29.3 & 112 & 27.4 & 1.7 & 0.431 \\
\hline $1-4$ & 127 & 35.8 & 165 & 40.3 & & \\
\hline 0 & 124 & 34.9 & 132 & 32.3 & & \\
\hline \multicolumn{7}{|c|}{ Family income (in minimum wages)* } \\
\hline$>0.5$ & 238 & 67.0 & 262 & 64.1 & 0.7 & 0.387 \\
\hline$\leq 0.5$ & 117 & 33.0 & 147 & 35.9 & & \\
\hline \multicolumn{7}{|l|}{ Unemployed } \\
\hline No & 269 & 75.8 & 299 & 73.1 & & \\
\hline Yes & 86 & 24.2 & 110 & 26.9 & 181.6 & $<0.001$ \\
\hline \multicolumn{7}{|c|}{ Age of first employment (in years) } \\
\hline $16+$ & 66 & 18.6 & 164 & 40.1 & 41.8 & $<0.001$ \\
\hline$\leq 15$ & 289 & 81.4 & 245 & 59.9 & & \\
\hline
\end{tabular}


Table 1. Continuation.

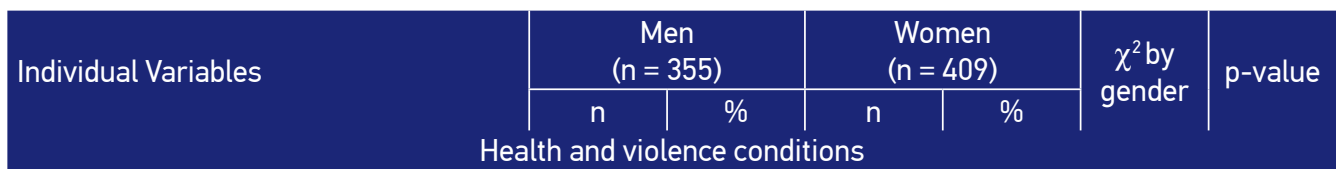

Health self-assessment

\begin{tabular}{l|c|c|c|c|c|c|c|}
\hline Very good/good & 162 & 45.6 & 177 & 43.3 & 4.7 & 0.095 \\
\hline $\begin{array}{l}\text { Average } \\
\text { Poor/very poor }\end{array}$ & 141 & 39.7 & 189 & 46.2 & & \\
\hline $\begin{array}{l}\text { Diagnosis of chronic illnesses } \\
\text { No }\end{array}$ & 159 & 44.8 & 119 & 29.1 & 20.2 & $<0.001$ \\
\hline $\begin{array}{l}\text { Yes } \\
\text { Diagnosis of psychiatric disorders }\end{array}$ & 196 & 55.2 & 290 & 70.9 & & \\
\hline No & 342 & 96.3 & 395 & 96.6 & 0.1 & 0.858 \\
\hline Yes & 13 & 3.7 & 14 & 3.4 & & \\
\hline
\end{tabular}

Physical or sexual violence

\begin{tabular}{l|c|c|c|c|c|c|c} 
No & 345 & 97.2 & 399 & 97.6 & 0.1 & 0.748 \\
\hline $\begin{array}{l}\text { Yes } \\
\text { Use of services in the past 12 months }\end{array}$ & 10 & 2.8 & 10 & 2.4 & & \\
\hline $\begin{array}{l}\text { Yes } \\
\text { No }\end{array}$ & 152 & 42.8 & 231 & 56.5 & 14.2 & $<0.001$ \\
\hline $\begin{array}{l}\text { Rating of overall access to healthcare services } \\
\text { Good }\end{array}$ & 203 & 57.2 & 178 & 43.5 & \\
\hline Average & 165 & 46.5 & 198 & 48.4 & 0.3 & 0.845 \\
\hline Poor & 85 & 23.9 & 92 & 22.5 & & \\
\hline
\end{tabular}

\begin{tabular}{|c|c|c|c|c|c|c|}
\hline \multicolumn{7}{|c|}{ Coping strategies } \\
\hline Yes & 338 & 95.2 & 33 & 8.1 & 3.3 & 0.068 \\
\hline No & 17 & 4.8 & 376 & 91.9 & & \\
\hline \multicolumn{7}{|c|}{ Participation in religious activities } \\
\hline Yes & 242 & 68.2 & 332 & 81.2 & 17.2 & $<0.001$ \\
\hline No & 113 & 31.8 & 77 & 18.8 & & \\
\hline \multicolumn{7}{|c|}{ Participation in group activities } \\
\hline Yes & 144 & 40.6 & 71 & 17.4 & 50.6 & $<0.001$ \\
\hline No & 211 & 59.4 & 378 & 82.6 & & \\
\hline \multicolumn{7}{|c|}{ Participation in volunteer work } \\
\hline Yes & 98 & 27.6 & 67 & 16.4 & 14.1 & $<0.001$ \\
\hline No & 257 & 72.4 & 342 & 83.6 & & \\
\hline \multicolumn{7}{|c|}{ Regular physical activity } \\
\hline Yes & 120 & 33.8 & 74 & 18.1 & 24.8 & $<0.001$ \\
\hline No & 235 & 66.2 & 335 & 81.9 & & \\
\hline \multicolumn{7}{|l|}{ TV watcher } \\
\hline Yes & 261 & 73.5 & 324 & 79.2 & 3.4 & 0.064 \\
\hline No & 94 & 26.5 & 85 & 20.8 & & \\
\hline \multicolumn{7}{|c|}{ Alcohol consumption } \\
\hline Yes & 155 & 43.7 & 296 & 72.4 & 64.8 & $<0.001$ \\
\hline No & 200 & 56.3 & 113 & 27.6 & & \\
\hline \multicolumn{7}{|l|}{ Tobacco smoking } \\
\hline Never smoked & 230 & 64.8 & 332 & 81.2 & 26.2 & $<0.001$ \\
\hline Smoke/smoked & 135 & 35.2 & 77 & 18.8 & & \\
\hline
\end{tabular}

*minimum wage of 545.00 brazilian Real at the time of the data collection. 


\section{BIVARIATE ANALYSIS}

For men, the factors statistically associated with depression $(\mathrm{p} \leq 0.05)$ were: being 41 years of age or older and having poor/very poor health self-assessment, previous diagnosis of chronic illnesses, poor access to health services, and not participating in physical activity. The remaining variables considered for the multivariate model ( $\mathrm{p} \leq 0.20$ ) were: lower schooling, unemployment, placement in the job market before the age of 16 , average access to health services, nonparticipation in group activities, alcohol consumption, and history of tobacco smoking.

For women, the factors statistically associated with depression $(\mathrm{p} \leq 0.05)$ were: selfdeclaration of race as not black, placement in the job market before the age of 16, poor/ very poor health self-assessment, previous diagnosis of psychiatric disorders, participation in volunteer work, history of tobacco smoking, and poor or average rating of overall access to healthcare services. The remaining variables considered for the multivariate model $(\mathrm{p} \leq 0.20)$ were: being 41 years of age or older, having previous diagnosis of chronic illnesses, having suffered physical or sexual violence, and not watching TV.

\section{MULTIVARIATE ANALYSIS}

When carrying out the multivariate analysis for male participants (Table 2), adjusted by all bivariate analyses with p-value up to 0.20 , it was observed that there was a higher probability of identifying prevalence of depression among men who reported that a doctor had already diagnosed them with a chronic illness, such as tuberculosis and hypertension, among others $(\mathrm{PR}=5.1 ; 95 \% \mathrm{CI} 1.8-14.8)$, than among men without any previous diagnoses. Depression was

Table 2. Multivariate analysis for men and women, Vitória da Conquista, BA, 2011 ( $n=764)$.

\begin{tabular}{l|c|c|c|}
\hline \multirow{2}{*}{ Variables } & \multicolumn{3}{|c}{ Men } \\
\cline { 2 - 4 } & PR & $95 \% \mathrm{Cl}$ & $\mathrm{p}$-value \\
\hline Diagnosis of chronic illnesses & 5.1 & $1.8-14.8$ & 0.002 \\
\hline Poor/very poor health self-assessment & 2.3 & $1.1-5.1$ & 0.036 \\
\hline Poor rating of overall access to healthcare services & 1.9 & $1.1-4.1$ & 0.049 \\
\hline Variables & & Women & \\
\hline Diagnosis of psychiatric disorder & PR & $95 \% \mathrm{Cl}$ & $\mathrm{p}-\mathrm{value}$ \\
\hline Poor/very poor health self-assessment & 2.4 & $1.2-4.8$ & 0.011 \\
\hline Non-black race/color & 2.4 & $1.2-4.8$ & 0.011 \\
\hline History of tobacco smoking & 1.5 & $1.3-1.9$ & 0.015 \\
\hline
\end{tabular}

PR: adjusted prevalence ratio; $95 \% \mathrm{Cl}$ : 95\% confidence interval. 
also more frequent among those who assessed their own health as poor/very poor in comparison to those who assessed their health as good/very good $(\mathrm{PR}=2.3 ; 95 \% \mathrm{CI} 1.11-5.1)$ and among men whose rating of overall access to healthcare services was poor in comparison to those whose rating of overall access to healthcare services was good $(\mathrm{PR}=1.9 ; 95 \% \mathrm{CI} 1.1-4.1)$.

For women, the factors associated with depression show a higher probability of positive screening among women who reported that a doctor had already diagnosed them with psychiatric disorders than among women without any previous psychiatric disorders $(\mathrm{PR}=2.4$; $95 \%$ CI $1.2-4.8$ ). Similarly to men, there was a higher chance to positively identify for depression among women who assessed their own health as poor than among those who assessed their health as good $(\mathrm{PR}=2.4 ; 95 \% \mathrm{CI} 1.1-4.8)$. Moreover, women who declared themselves as not black had a higher chance to positively identify for depression than the ones who declared themselves as black ( $\mathrm{PR}=1.5 ; 95 \% \mathrm{CI} 1.3-1.9)$ and those who had a history of tobacco smoking than the ones who never smoked (PR $=1.9 ; 95 \%$ CI $1.2-3.2)$. The models were adequate for both men (Goodness-of-fit 138.63; $\mathrm{p}=0.397$ and Omnibus 28.69; $\mathrm{p}<0.001$ ) and women (Goodness-of-fit 216.09; $\mathrm{p}=0.531$ and Omnibus 4.61; $\mathrm{p}=0.032$ ).

\section{DISCUSSION}

The investigated communities are rural and the descriptive analyses showed that the Quilombola men had a more "active" profile than women, which has been associated with the social roles of masculinity in the general Brazilian population. ${ }^{26}$. That profile indicates the man as the family provider, who must carry out labor activities away from the household, someone more rational and straightforward ${ }^{27}$. It further shows that men engage in more physical activities and participate in group recreational actions (e.g., soccer), in addition to showing increased consumption of psychoactive substances such as alcohol and tobacco ${ }^{26,27}$. The conclusion that men residing in Quilombola communities follow the expected pattern in the Brazilian population as more "masculine" may help us to understand why the factors associated with depression among men represent physical health aspects (presence of chronic physical illnesses, poorer health assessment) or more specific problems (access to health services). The study on gender roles in Brazil indicates that falling physically ill is more common among people who adopt more masculine social roles, while femininity is associated with greater emotional instability and the development of psychological/psychiatric disorders ${ }^{27}$.

The Quilombola women also follow the most expected social role for females, reporting more chronic diseases and having more individual leisure/coping activities, such as participation in religious practices. Investigations into gender roles in the Brazilian culture still associate women with a more submissive and receptive attitude than men, which would lead them to marrying older men and staying more at home, where they would take on roles of caretakers of the home and the family ${ }^{27}$, as observed among the studied Quilombola women.

Results showed that the factors associated with depression in adults residing in Quilombola communities in Vitória da Conquista, Bahia, differ between men and women, although there 
are no gender differences in the prevalence of depression in this population ${ }^{21}$. The presence of different factors associated with depression for men and women had already been indicated in a previous study ${ }^{28}$, in which it was observed that not living with a partner and having a less comprehensive social network were associated with depression among elderly men, but that such factors were not related to depression in the investigated elderly women. Other studies have shown that men and women differ in the relationships they establish with health ${ }^{7}$ and in the way they use healthcare services, including in the Quilombola population ${ }^{29}$.

In this study, an association between depression and the poorest health self-assessment, for both men and women, was observed, which indicates that the way a person assesses their own health condition is a very important factor for the understanding of the development of psychiatric disorders, regardless of gender. Studies on mental illnesses in other populations ${ }^{5,7}$ and researches concerning other health conditions in the Quilombola population ${ }^{18,19,21}$ had already indicated the relationship between the poorest health self-assessment and falling physically ${ }^{18,19,30}$ and mentally ${ }^{21}$ ill. That is still an understudied aspect in health interventions, but that affects the demand for healthcare services and the compliance with treatments of several diseases ${ }^{31-33}$, which shows its importance and the need for its inclusion in interventions in the Quilombola population.

The presence of pre-existing conditions was also significant for both genders, and the type of disease varies. For men, previous diagnosis of chronic physical diseases has been related to depression, while for women the association occurred between depression and previous diagnosis of psychiatric disorders. These observations highlight the importance of knowing and treating chronic health conditions in low-income populations. The presence of a chronic disease, especially if untreated, denotes the poor access to healthcare services, jeopardizes (in a real or imaginary manner) the ability to develop daily activities and worsens patients' self-assessment of health. In poor communities, such as the Quilombola communities researched, the diagnosis of a chronic disease can usually be made only in more severe cases in which the symptoms can be disabling and, therefore, may adversely affect work activities or the functional independence of the individual, representing a risk to the safety of the family's livelihood ${ }^{26,27}$. The observation of the association between physical illness and depression, found between Quilombola men, can be explained accordingly. In the Quilombola communities, most men work as farm workers, and a chronic disease could prevent this activity, causing constant concern for such men with regard to the security of family support, thereby facilitating the emergence of depressive disorder.

Also, to get a proper diagnosis of chronic physical illnesses or psychiatric disorders, the individual needs to consult a professional and sometimes do laboratory or imaging tests. The higher the level of diagnostic complexity, as in mental disorders, the greater the difficulty of access for residents of poor or rural populations ${ }^{34}$. Given the precarious conditions of access to healthcare services by the Quilombola population, the need for consultation with medical specialists and/or additional tests can deprive a significant portion of the population of a diagnosis and the treatment needed. This condition worsens when the disorder is of a mental nature. Among the Quilombola respondents, more than half the women (55.2\%) and 
$44 \%$ of men reported having received previous medical diagnosis of chronic diseases, but only $3.5 \%$ reported having received previous diagnosis of psychiatric disorders, a much lower percentage in comparison with that of respondents screened for depression in the study.

The relationship between depression and the poor access to healthcare services proves to be even more immediate among Quilombola men. The Quilombola population is predominantly rural, which has been identified as a factor associated with poor access to healthcare services ${ }^{15,16,20}$ and related to higher prevalence of depression in other studies ${ }^{21,34}$. In the researched communities in the COMQUISTA Project, a previous study ${ }^{20}$ brought out the precariousness of access to healthcare services, reporting that only three out of five communities in the project had facilities to hold a Basic Healthcare Unit to service the community. In the others, healthcare procedures were performed in schools or in the homes of community workers. The authors also showed that the Quilombolas used healthcare services less often than the Brazilian population in general, and that the amount of uses differed according to gender. Women used healthcare services more frequently than men, corroborating findings of other studies on use frequency ${ }^{34}$ and better disease monitoring among women ${ }^{35}$. The greater number of women searching for healthcare services can help identifying and treating their illnesses, which causes an artificial increment in the estimated prevalence of some diseases among them, nevertheless enabling better prognostics on the their evolution.

Two other factors proved to be associated with depression among women are: history of tobacco smoking and self-declaration of race as not black. Although in the group of Quilombolas researched there were more men than women smoked, the association between smoking and depression occurred only among women. Such result can indicate the existence of a higher level of anxiety among women, who would seek smoking in a way to deal with anxiogenic situations, which has proven to be a coping strategy of little effect. This interpretation is based on previous findings regarding history of tobacco smoking, which associate smoking with higher prevalence of mood and psychiatric disorders among women ${ }^{34,36}$.

The connection between depression and the self-declaration of race as not black observed in Quilombola women raises some hypothesis. An explanation of such result is that the association arises from continuous stigmatized life experiences of self-declaration of race as black in Brazil ${ }^{16,17}$. However, considering the methodology choices for this study, the reasons behind such observation are impossible to be probed. Future research with methodology designed to answer this kind of question must be done in order to clarify the relationship between race/color, social stigma and depression in Quilombola women.

In addition to this limitation, it is necessary to point out some others. The choice of a cross-sectional study methodology prevents the establishment of direct causality between the event and the explanatory variables researched. Another limitation refers to the use of personal reports with no clinical confirmation. The statistical power of the sample also represented a limitation to the estimation of the prevalence of depression stratified by gender, as this was not one of the original goals of the research project. Thus, further studies are necessary to elicit the differences in depression symptoms in men and women, in addition to forward the investigation on the occurrence of depression in the Quilombola population. 


\section{CONCLUSION}

Considering the existence of chronic illnesses as well as of people's individual assessment on their own health proved relevant to both genders, in addition to demonstrate the need for improvement of Quilombolas' access to healthcare services. The results also brought out the fact that interventions focused on identifying chronic physical diseases can contribute more to fighting depression among men, while anti-smoke interventions as well as those which identify other psychiatric disorders can be more effective in women. Making healthcare teams aware of these differences and enabling them to use screening instruments for various illnesses can direct patient referrals to specialized medical care, also helping the early detection and treatment of several conditions such population may have, including depression.

\section{REFERENCES}

1. Kessler RC, Birnbaum HG, Shahly V, Bromet E, Hwang I, McLaughlin KA, et al. Age differences in the prevalence and co-morbidity of DSM-IV major depressive episodes: results from the WHO World Health Survey Initiative. Depress Anxiety 2010; 27(4): 351-64.

2. Instituto Brasileiro de Geografia e Estatísticas (IBGE). Pesquisa Nacional por Amostra de Domicílios. Um panorama da saúde no Brasil: acesso e utilização dos serviços, condições de saúde e fatores de risco e proteção à saúde 2008. Rio de Janeiro: IBGE; 2010.

3. Bromet E, Andrade LH, Hwang I, Sampson NA, Alonso J, Girolamo G, et al. Cross-national epidemiology of DSM-IV major depressive episode. BMC Med 2011; 9: 90.

4. Marcus M, Yasami MT, van Ommeren M, Chisholm D, Saxena S. Depression: a global public health Concern, 2012 [Internet] 2012. Disponível em: http://www. who.int/mental_health/management/depression/ who_paper_depression_wfmh_2012.pdf [Acessado em 30 de maio de 2014].

5. Molina MRAL, Wiener CD, Branco JC, Jansen K, Souza LDM, Tomasi E, et al. Prevalência de depressão em usuários de unidades de atenção primária. Rev Psiquiatr Clín 2012; 39(6): 194-7.

6. Zammit S, Owen MJ. Stressful life events, 5-HTT genotype and risk of depression. Br J Psychiatry 2006; 188: 199-201.

7. Hofmann SG, Anu Asnaani MA, Hinton DE. Cultural aspects in social anxiety and social anxiety disorder. Depress Anxiety 2010; 27(12): 1117-27.
8. Southwick SM, Charney DS. The Science of resilience: implications for the prevention and treatment of depression. Science 2012; 338(6103): 79-82.

9. Khan A, Brodhead AE, Schwartz KA, Kolts RL, Brown WA. Sex differences in antidepressant response in recent antidepressant clinical trials. J Clin Psychopharmacol 2005; 25(4): 318-24.

10. Loewhental K, Goldblatt V, Gordon T, Lubitsch G, Bicknell H, Fellowes D, et al. Gender and depression in Anglo-Jewry. Psychol Med 1995; 25(5): 1051-63.

11. WilhemK, Parker G. Sex differencesin the lifetime depression rates: fact or artifact? Pshycol Med 1994; 24(1): 97-111.

12. Van de Velde S, Bracke P, Levecque K. Gender differences in depression in 23 European countries: cross-national variation in the gender gap in depression. Soc Sci Med 2010; 71(2): 305-13.

13. Brown DR, Ahmed F, Gary LE, Milbum NG. Major depression in a community sample of African Americans. Am J Psychiatry 1995; 152(3): 373-8.

14. Levav I, Kohn R, Dohrenwend BP, Shrout PE, Skodol AE, Schwartz S, et al. An epidemiological study of mental disorders in a 10-year cohort of young adults in Israel. Psychol Med 1993; 23(3): 691-707.

15. Lima FL, Caixeta LF, Oliveira ME, Peleja AAC, Barros NM, Oliveira PHT. Prevalência de transtornos mentais entre indígenas da etnia Karajá em serviço de atenção primária em psiquiatria. In: $63^{a}$ Reunião Anual da Sociedade Brasileira para o Progresso da Ciência. Goiânia: SBPC; 2011. Disponível em: http://200.137.221.67/ conpeex / 2010/online/artigos/pibic/pibic_miolo_2. pdf (Acessado em 30 de junho de 2014). 
16. Brasil. Secretaria Especial de Políticas de Promoção da Igualdade Racial. Relatório de avaliação do plano plurianual 2008-2011. Brasília: Secretaria Especial de Políticas de Promoção de Igualdade Racial; 2009. Disponível em: http: / / www.biblioteca.presidencia.gov. br/publicacoes-oficiais-1 / catalogo/ orgao-essenciais / secretaria-de-politicas-de-promocao-de-igualdaderacial/relatorio-de-avaliacao-do-plano-plurianual2008-2011(Acessado em 28 de janeiro de 2015).

17. Lindoso D. A razão quilombola: estudos em torno do conceito quilombola de nação etnográfica. Maceió: EDUFAL; 2011.

18. Silva JAN. Condições sanitárias e de saúde em Caiana dos Crioulos, uma comunidade Quilombola do Estado da Paraíba. Saúde Soc 2007; 16(2): 111-24.

19. Souza CL, Barroso SM, Guimaraes MDC. Oportunidade perdida para diagnóstico oportunista de diabetes mellitus em comunidades quilombolas do sudoeste da Bahia. Ciênc Saúde Coletiva 2014; 19(6): 1653-62.

20. Silva MJG, Lima FSS, Hamann EM. Uso dos serviços públicos de saúde para DST/HIV/aids por comunidades remanescentes de Quilombos no Brasil. Saúde Soc 2010; 19(Suppl 2): 109-20.

21. Barroso SM, Melo APS, Guimarães MDC. Depressão em comunidades quilombolas no Brasil: triagem e fatores associados. Rev Panam Salud Publica 2014; 35(4): 256-63.

22. Bezerra VM, Medeiros DS, Gomes KO, Souzas R, Giatti L, Steffens AP, et al. Inquérito de saúde em comunidades quilombolas de Vitória da Conquista, Bahia, Brasil (Projeto COMQUISTA): aspectos metodológicos e análise descritiva. Ciênc Saúde Coletiva 2014; 19(6): 1835-47.

23. Osório FL, Mendes AV, Crippa JA, Loureiro SR. Study of the discriminative validity of the PHQ-9 and PHQ-2 in a sample of Brazilian women in the context of primary health care. Perspect Psychiatr Care 2009; 45(3): 216-27.

24. Pasquali L. TRI - Teoria de Resposta ao Item: teoria, procedimentos e aplicações. 1 ed. Brasília: Laboratório de Pesquisa em Avaliação e Medida - LabPAM; 2007.

25. Hosmer DW, Lemeshow S. Applied Logistic Regression. New York: John Wiley and Sons; 2000.
26. Acosta, F, Andrade A, Bronz A. Conversas homem a homem: grupo reflexivo de gênero. Rio de Janeiro: Instituto Noos; 2004.

27. Brito MNC. Gênero e cidadania: referenciais analíticos. Rev Est Fem 2001; 9(1): 291-8.

28. Sonnenberg CM, Deeg DJ, van Tilburg TG, Vink D, Stek ML, Beekman AT. Gender differences in the relation between depression and social support in later life. Int Psychogeriatr 2013; 25(1): 61-70.

29. Gomes KO, Reis EA, Guimarães MDC, Cherchiglia ML. Utilização de serviços de saúde por população quilombola do Sudoeste da Bahia, Brasil. Cad Saúde Pública 2013; 29(9): 1829-42.

30. Volochko AA. Saúde nos Quilombos. In: Volochko A, Batista LE. Saúde nos Quilombos. São Paulo: Instituto de Saúde, SESSP; 2009. p. 147-68.

31. Faustino QM, Seidl EMF. Intervenção cognitivocomportamental e adesão ao tratamento em pessoas com HIV/Aids. Psic Teor e Pesq 2010; 26(1): 121-30.

32. Mezuk B, Rafferty JA, Kershaw KN, Hudson D, Abdou $\mathrm{CM}$, Lee $\mathrm{H}$, et al. Reconsidering the role of social disadvantage in physical and mental health: stressful life events, health behaviors, race, and depression. Am J Epidemiol 2010; 172(11): 1238-49.

33. Dias-da-Costa JS, Gigante DP, Horta BL, Barros FC, Victora CG. Utilização de serviços de saúde por adultos da coorte de nascimentos de 1982 a 2004-5, Pelotas, RS. Rev Saúde Pública 2008; 42(Suppl 2): 51-9.

34. Castro MGT, Oliveira MS, Araujo RB, Pedroso RS. Relação entre gênero e sintomas depressivos e ansiosos em tabagistas. Rev Psiquiatr Rio Gd Sul 2008; 30(1): 25-30.

35. Ryba MM, Hopko DR. Gender differences in depression: assessing mediational effects of overt behaviors and environmental reward through daily diary monitoring. Depress Res Treat 2012; 865679.

36. Barros FCR. Prevalência do tabagismo e seus fatores associados entre pacientes com transtorno mental no Brasil [Dissertação de mestrado]. Belo Horizonte: Universidade Federal de Minas Gerais; 2012.

Received on: 06/13/2014

Final version presented on: 08/07/2014 Accepted on: 09/30/2014 